\title{
AN OVERVIEW OF ENTRIES LISTING JOURNALS [J]
}

(See also, for individual author journals, references in entries $\mathrm{M}-60$ and $\mathrm{S}-\mathbf{5 0}$.)

\section{F-10 Scholarly Journals in History}

H-8 Some Journals Concerned with the Administration, Study, and Use of Archives and Manuscripts Collections

-15 Scholarly Journals in Language, Linguistics, and Philology

-106 Scholarly Journals in Translation Theory and Practice

K-23 Scholarly Journals in Folklore Studies

L-9 Scholarly Journals in Comparative and General Literature

L-48 Scholarly Journals in Classical Studies

L-57 Scholarly Journals in Modern Languages and Literatures

L-63 Scholarly Journals in the Romance Languages and Literatures

L-78 Scholarly Journals in French Studies

L-88 Scholarly Journals in Italian Studies

L-95 Scholarly Journals in Hispanic and HispanicAmerican Studies

L-108 Scholarly Journals in the Germanic Languages and Literatures

L-128 Scholarly Journals in Slavic and East European Studies

L-138 Scholarly Journals in African Studies

L-148 Scholarly Journals in Asian Studies

L-179 Scholarly Journals in Children's Literature

L-189 Scholarly Journals in Women's Studies

M-25 Scholarly Journals in English and American Literature

M-78 Scholarly Journals in Scottish Literature and Scottish Studies

M-93 Scholarly Journals in Anglo-Irish Literature, Irish Studies, and Celtic Studies

M-98 Scholarly Journals in Anglo-Welsh Literature and Welsh Studies

M-108 Scholarly Journals in Commonwealth Literature and in World Literature Written in English

M-118 Scholarly Journals in African Literature Written in English
M-128 Scholarly Journals in Australian Literature

M-148 Scholarly Journals in Canadian Literature in English M-158 Scholarly Journals in Anglo-Indian Literature

M-168 Scholarly Journals in New Zealand Literature and the Other English Literatures of the South Pacific (Excluding Australia)

M-178 Scholarly Journals in West Indian Literature in English

N-18 Scholarly Journals in Medieval Studies

0-18 Scholarly Journals in Renaissance Studies

0-58 Scholarly Journals in Shakespeare Studies

0-78 Scholarly Journals in Neo-Latin Studies

P-18 Scholarly Journals in Restoration and EighteenthCentury Studies

Q-18 Scholarly Journals in Nineteenth-Century Studies

R-18 Scholarly Journals in Modem Studies

S-18 Scholarly Joumals in American Literature and American Studies

T-8 Scholarly Journals Concerned Exclusively or Primarily with English or American Poetry and Verse

U-18 Scholarly Journals in Drama, Theater, and Theater History

U-129 Scholarly Journals in Film Studies

W-8 Scholarly Journals in Prose Fiction Studies

$X-13$ Scholarly Journals in Literary Theory and Literary Criticism

X-38 Scholarly Journals in Literature and the Other Arts and Sciences

X-165 Scholarly Joumals in Rhetoric, Communications and Discourse Theory, Stylistics, and Composition

Y-38 Scholarly Journals in Bibliography and Textual Criticism and in the History of Printing and the Book Trade

Y-98 Scholarly Journals on Libraries and Librarianship

Z-18 Professional Journals in English Studies

Z-58 Scholarly Joumals Publishing Research Notes and Queries

Z-138 Scholarly Journals Concemed with College-Level Education and English Education

Z-158 Journals of Particular Interest to Humanists 
